\title{
EFFECT OF IRRIGATION LEVELS ON GROWTH AND FRUITING OF MANFALOUTY POMEGRANATE TREES
}

\author{
(Received:26.10.2009) \\ By \\ M. M. Khattab, A. E. Shaban, A. A. El-Shreif ${ }^{*}$ and A. S. El-Souda* \\ Pomology Department, Faculty of Agriculture, Cairo University, and *Horticulture Research \\ Institute, Agricultural Research Center, Giza, Egypt.
}

\begin{abstract}
This investigation was carried out in two successive seasons (2007 and 2008) on 20 year old pomegranate cv. Manfalouty (Punica granatum L.) trees grown at El-Kassasien Research Station, Ismailia Governorate in sandy soil under drip irrigation system. The experiment was designed to study the response of pomegranate trees to different irrigation levels and their effect on vegetative growth and fruit quality. The trees received the following five irrigation levels: 7, 9, 11, 13 or $15 \mathrm{~m}^{3} /$ tree/year. The results indicated that the highest irrigation level of $15 \mathrm{~m}^{3} /$ tree/year enhanced vegetative growth by increasing shoots length, number of leaves per shoot and leaf area. Also, it increased the number of flowers per shoot, fruit set, fruit retention, fruit dimensions, fruit volume, fruit grains, yield and fruit cracking. Using irrigation level of $13 \mathrm{~m}^{3} /$ tree/year recorded the highest leaf mineral contents of $\mathrm{N}, \mathrm{P}, \mathrm{K}$ and Ca. Also, increased fruit juice, TSS/ acid ratio and water use efficiency (WUE) and gave the lowest fruit cracking. Meanwhile, using the lowest irrigation level of $7 \mathrm{~m}^{3} /$ tree/year decreased vegetative growth, yield and fruit weight, with increasing fruit cracking, fruit TSS, acidity, sugar, V.C. and anthocyanin content.
\end{abstract}

Key words: fruiting, growth, irrigation, pomegranate tress.

\section{INTRODUCTION}

Water is one of the most important components in the biological function (Salisbury and Ross, 1985). There is an increasing demand on water resources used for irrigation, and a need to maximize agriculture water utilization efficiency. Many approaches for measuring soil water status to guide irrigation are used to optimize yield of fruit trees (Devid et al., 1999). The amount and quality of available irrigation water of the arid and semi-arid regions of the world such as Egypt, are the main limiting factors for extension agriculture (Beaumont, 1993). Therefore plant growth and development are retarded when water supply was restricted (Wright and Stark, 1990).

Many investigations have focused on the effect of irrigation levels on vegetative growth, yield, fruit quality as well as fruit cracking of pomegranate fruit (Afria et al., 1998, Prasad et al., 2003 and Meti et al., 2008)

Pomegranate $c v$. Manfalouty is considered one of the most important pomegranate cultivars grown successfully in Egypt, and the biggest area is located in Assuit region (5809 feddans according to the Central Administration for Agriculture Economic Ministry of Agriculture, A.
R. E., 2007) where they use flooding irrigation which wastes a big amount of water while drip irrigation saves up to $50-66 \%$ of water and increases yield by $30-40 \%$ compared to flooding irrigation (Behnia, 1999 and Chopade et al., 2001).

There is little information about water use of pomegranate trees in relation to growth and productivity. Therefore, this experiment was designed to determine water level in relation to pomegranate tree growth, fruit quality and yield.

\section{MATERIALS AND METHODS}

This investigation was carried out through 2007 and 2008 seasons on 20 year old pomegranate cv. Manfalouty (Punica granatum, L.). Trees under investigation were grown in a sandy soil under drip irrigation system. Trees were planted at five meters apart at El-Kassasien Research Station, Ismailia Governorate. Trees received the normal cultural practices according to the recommendations of Horticulture Research Institute (H.R.I.), Ministry of Agriculture, Egypt. The study involved five treatments; each treatment comprised three replicates (an individual tree/replicate) and were well managed. The main objective of the present investigation was to find 
out the irrigation levels that gave good growth and fruiting of pomegranate. The common irrigation rate that is used at this station is $11 \mathrm{~m}^{3} /$ tree/season (1848 $\mathrm{m}^{3} /$ feddan/year) according to the recommendations of the Ministry of Agriculture. Pomegranate is irrigated in Israel with 5000 $\mathrm{m}^{3} /$ ha/year about ( $2000 \mathrm{~m}^{3} /$ feddan/year) according to Blumenfeld (1995). Trees were given irrigation water levels as follows:

1) $7 \mathrm{~m}^{3} /$ tree/year $\left(1176 \mathrm{~m}^{3} /\right.$ feddan/year $)$,

2) $9 \mathrm{~m}^{3} /$ tree/year $\left(1512 \mathrm{~m}^{3} /\right.$ feddan/year $)$,

3) $11 \mathrm{~m}^{3} /$ tree/year $\left(1848 \mathrm{~m}^{3} /\right.$ feddan/year),

4) $13 \mathrm{~m}^{3} /$ tree/year $\left(2184 \mathrm{~m}^{3} /\right.$ feddan/year $)$

5) $15 \mathrm{~m}^{3} /$ tree/year $\left(2520 \mathrm{~m}^{3} /\right.$ feddan/year $)$.

Irrigation treatments varied with the change of the developmental stage of the plant.

The following parameters were measured at the end of the season.

-Length of the new developed shoot $(\mathrm{cm})$, number of leaves per shoot and leaf area $\left(\mathrm{cm}^{2}\right)$.

-Leaf mineral content: ten leaves from the middle part of shoots were taken in July of both seasons to determine the total nitrogen by the modified micro-Kejldahl method (Naguib, 1969). Phosphorus content was coloremetically estimated according to Murphy and Riely (1962), potassium was determined using flame photometer (Brown and Lilleland, 1946) and calcium by an Atomic Absorption Spectrophotometer (Perkin Elmer3300) according to Chapman and Pratt (1961).

-Flowering and fruiting attributes:

Number of flowers per shoot was counted at balloon stage. Fruit set (\%) was calculated by the following equation:

Fruit set $\%=$ number of set fruit $/$ total number of flowers X 100.

Fruit drop (\%) was calculated by the following equation :

Fruit drop $\%=$ total number of fruit set - total number of fruits at harvest time / total number of fruit set X 100.

Fruit retention (\%) was determined by counting the number of fruits at harvest time/ initial number of fruit set. Tree yield $(\mathrm{kg})$ was estimated at harvest.

Nine fruits were taken at harvest from each treatment for determination of the following physical and chemical properties:

Fruit weight $(\mathrm{gm})$, fruit size $\left(\mathrm{cm}^{3}\right)$, fruit dimensions $(\mathrm{cm})$, grain weight $(\%)$, juice volume $(\%)$, peel weight $(\%)$, percentage of fruit cracking/tree at harvest time, juice total soluble solids (\%), titrateable acidity (\%) according to A.O.A.C., (1985), TSS/acid ratio, Vitamin C content (mg L-ascorbic acid /100 ml juice) according to A.O.A.C., (1985). Total sugar contents were determined calorimetrically according to Dubois et al.(1956). Total anthocyanin content in fruit juice was determined as described by Hsia et al.(1965).

Water use efficiency was calculated as obtained yield in each treatment divided by the amount of water (as described by Hussein, 2004).

Experiments conducted in this study followed the randomized complete blocks design. The obtained data were tabulated and statistically analyzed according to Snedecor and Cochran (1980). Differences between treatments were compared by Duncan's multiple range test according to Duncan (1955).

\section{RESULTS AND DISCUSSION 3.1. Effect of irrigation levels on vegetative growth}

Data in Table (1) show the effect of irrigation levels on shoot length, number of leaves per shoot and leaf area. Regarding shoot length, there were significant differences between all treatments, the highest shoot length $(30.23$ and $29.76 \mathrm{~cm}$ in the first and second seasons respectively) resulted from irrigation with $15 \mathrm{~m}^{3} /$ tree/year while the lowest significant one (20.77 and $18.92 \mathrm{~cm})$ resulted from irrigation at $7 \mathrm{~m}^{3} /$ tree/year. In addition, the number of leaves/ shoot increased significantly by increasing irrigation. Irrigation at $15 \mathrm{~m}^{3} /$ tree/year gave the highest leaf number/ shoot, while the lowest number was recorded with irrigation at $7 \mathrm{~m}^{3} /$ tree/ year. Concerning leaf area, it is noticeable that reducing irrigation rate

Table (1): Effect of irrigation levels on shoot length (cm), number of leaves / shoot and leaf area $\left(\mathrm{cm}^{2}\right)$ of pomegranate $\mathrm{c} \mathrm{v}$. Manfalouty in the 2007 and 2008 seasons

\begin{tabular}{|c|c|c|c|}
\hline $\begin{array}{c}\text { Irrigation } \\
\text { levels } \\
\left(\mathrm{m}^{3} / \text { tree/ }\right. \\
\text { year) }\end{array}$ & $\begin{array}{c}\text { Shoot } \\
\text { length }(\mathrm{cm})\end{array}$ & $\begin{array}{l}\text { number of } \\
\text { leaves / shoot }\end{array}$ & $\begin{array}{l}\text { Leaf area } \\
\left(\mathrm{cm}^{2}\right)\end{array}$ \\
\hline \multicolumn{4}{|c|}{2007 Season } \\
\hline 7 & 20.77 e & 20.00 e & $4.91 \mathrm{e}$ \\
\hline 9 & $22.70 \mathrm{~d}$ & $21.03 \mathrm{~d}$ & $5.36 \mathrm{~d}$ \\
\hline 11 & 25.07 c & 22.80 c & $5.77 \mathrm{c}$ \\
\hline 13 & $28.83 \quad b$ & 24.47 b & $6.68 \mathrm{~b}$ \\
\hline 15 & $30.23 \mathrm{a}$ & 25.83 a & 7.13 a \\
\hline \multicolumn{4}{|c|}{2008 Season } \\
\hline 7 & 18.92 e & $18.61 \mathrm{e}$ & $4.45 \mathrm{~d}$ \\
\hline 9 & $20.89 d$ & 20.09 d & $5.38 \mathrm{c}$ \\
\hline 11 & 23.96 c & 22.09 c & $5.60 \mathrm{c}$ \\
\hline 13 & 27.12 b & 23.59 b & $6.37 \mathrm{~b}$ \\
\hline 15 & 29.76 a & 25.31 a & $6.91 \mathrm{a}$ \\
\hline
\end{tabular}

not significantly different at 0.05 level of probability 
considerably reduced leaf area. The highest significant of leaf area was obtained by irrigation at $15 \mathrm{~m}^{3} /$ tree/ year while irrigation level at $7 \mathrm{~m}^{3} /$ tree/ year gave the significantly lower values in both seasons.

Generally, increasing irrigation levels from 7 to $15 \mathrm{~m}^{3} /$ tree/year enhanced vegetative growth of pomegranate by increasing shoot length, number of leaves per shoot and leaf area. It can be explained that water stress decreases the cytokinin transport from roots to shoots and increase the amount of leaf abscisic acid. These changes in hormone balance cause a reduction in cell growth and leaf expansion. These results are in line with those obtained by Hussein (2004) on pear, Kandil and El-Feky (2006) on apricot, as they stated that shoot growth and leaf area were markedly increased by increasing irrigation rates. Also, Abou El-Wafa (2002), on pomegranate, stated that the lowest number of leaves per shoot was correlated with drought.

\subsection{Leaf mineral content ( $N, P, K, C a)$}

Data in Table (2) show leaf content of N, P, K and $\mathrm{Ca}$. The $\mathrm{N}$ content increased significantly by increasing irrigation level from 7 to 13 $\mathrm{m}^{3} /$ tree/season. Also, a slight reduction in $\mathrm{N}$

Table (2): Effect of irrigation levels on leaf mineral content (\%) of pomegranate $\mathrm{c} v$. Manfalouty in 2007 and 2008 seasons.

\begin{tabular}{|c|c|c|c|c|}
\hline $\begin{array}{c}\text { Irrigation } \\
\text { levels } \\
\text { (m²/tree/ } \\
\text { year) }\end{array}$ & $\mathbf{N}(\%)$ & $\mathbf{P}(\%)$ & $\mathrm{K}(\%)$ & Ca $(\%)$ \\
\hline \multicolumn{5}{|c|}{2007 Season } \\
\hline 7 & $1.80 \mathrm{c}$ & $0.22 \mathrm{~b}$ & $1.45 \mathrm{~d}$ & $1.30 \mathrm{~d}$ \\
\hline 9 & $1.83 \mathrm{c}$ & $0.23 \mathrm{ab}$ & $1.52 \mathrm{c}$ & $1.37 \mathrm{~cd}$ \\
\hline 11 & $1.88 \mathrm{bc}$ & $0.25 \mathrm{ab}$ & $1.58 \mathrm{bc}$ & $1.45 \mathrm{bc}$ \\
\hline 13 & $2.10 \mathrm{a}$ & 0.27 a & $1.66 \mathrm{a}$ & $1.51 \mathrm{~b}$ \\
\hline 15 & $1.95 \mathrm{~b}$ & 0.27 a & $1.61 \mathrm{ab}$ & $1.63 \mathrm{a}$ \\
\hline \multicolumn{5}{|c|}{2008 Season } \\
\hline 7 & $1.72 \mathrm{c}$ & $0.20 \mathrm{~b}$ & $1.34 \mathrm{~b}$ & $1.18 \mathrm{c}$ \\
\hline 9 & $1.76 \mathrm{bc}$ & $0.22 \mathrm{ab}$ & $1.30 \mathrm{~b}$ & $1.22 \mathrm{c}$ \\
\hline 11 & $1.81 \mathrm{bc}$ & $0.23 \mathrm{ab}$ & $1.44 \mathrm{a}$ & $1.43 \mathrm{~b}$ \\
\hline 13 & $2.03 \mathrm{a}$ & $0.25 \mathrm{a}$ & $1.50 \mathrm{a}$ & $1.52 \mathrm{ab}$ \\
\hline 15 & $1.90 \mathrm{ab}$ & $0.23 \mathrm{ab}$ & $1.44 \mathrm{a}$ & $1.60 \mathrm{a}$ \\
\hline
\end{tabular}

content was observed by increasing irrigation rate to $15 \mathrm{~m}^{3} /$ tree/ year in both seasons.

The highest significant leaf $\mathrm{P}$ content $(0.27$ $0.25 \%$ ) was recorded by irrigation at $13 \mathrm{~m}^{3} /$ tree/ year, while, irrigation at $7 \mathrm{~m}^{3} /$ tree/ year gave the significantly lower value $(0.22$ and $0.2 \%$ in the two seasons).

Regarding leaf $\mathrm{K}$ content, irrigation at 13 $\mathrm{m}^{3} /$ tree/ year produced the highest significant $\mathrm{K}$ content $(1.66-1.50 \%)$ in both seasons. On the other hand, irrigation at $7 \mathrm{~m}^{3} /$ tree/ year gave the lowest significant $\mathrm{K}$ content $(1.45-1.34 \%)$ in both seasons. The increase of leaf $\mathrm{N}, \mathrm{P}$ and $\mathrm{K}$ content with increasing irrigation rate was previously reported by Hussein (2004) on pear, Chauhan et al. (2005) on apple, as they found that nitrogen, phosphorous and potassium contents were increased under the condition of high irrigation treatment.

Regarding Ca content, it was cleared that the highest irrigation level $\left(15 \mathrm{~m}^{3} /\right.$ tree/ year) increased Ca content significantly compared with other irrigation levels. These results are in line with those reported by Ahmed (1994) on pomegranate, Chauhan et al. (2005) on apple as they indicated that leaf content of $\mathrm{Ca}$ was greater with the highest irrigation regimes than the lowest irrigation ones.

Reduction in leaf element contents with reducing irrigation amount is explained by a substantial decrease in transpiration rates and impaired active transport and membrane permeability, resulting in a reduced root absorbing power of nutrients.

\subsection{Effect of irrigation levels on fruiting and yield}

Results presented in Table (3) show the effect of irrigation levels on the number of flowers per shoot, fruit set, fruit retention and fruit drop. Considering flower number per shoot, there was a significant increase in the flower number/ shoot in both seasons associated with high rate of irrigation. Irrigation level at $15 \mathrm{~m}^{3} /$ tree/ year recorded the highest significant flower number/ shoot while the lowest significant flower number/ shoot was formed by irrigation at $7 \mathrm{~m}^{3} /$ tree/ year.

Regarding fruit set (\%), it is clear that there was a significant increase in the fruit set percentage in both seasons, associated with high rate of irrigation. Meanwhile, irrigation at $15 \mathrm{~m}^{3} /$ tree/ year recorded the highest fruit set percentage (33.40 and $30.10 \%$ in the 2007 and 2008 seasons, respectively) while the lowest fruit set percentage (23.27 and $21.18 \%$ ) was produced by irrigation level at $7 \mathrm{~m}^{3} /$ tree/ year in both seasons. 
The increase of flower number/shoot and fruit

Table (3): Effect of irrigation levels on flower number/ shoot, fruit set (\%), fruit retention (\%) and fruit drop (\%) of pomegranate $c v$.Manfalouty in the 2007 and 2008 seasons

\begin{tabular}{|c|c|c|c|c|}
\hline $\begin{array}{c}\text { Irrigation } \\
\text { levels } \\
\left(\mathbf{m}^{3} / \text { tree/ }\right. \\
\text { year })\end{array}$ & $\begin{array}{c}\text { Flower } \\
\text { number } \\
\text { / shoot }\end{array}$ & $\begin{array}{c}\text { Fruit } \\
\text { set } \\
(\%)\end{array}$ & $\begin{array}{c}\text { Fruit } \\
\text { retention } \\
(\%)\end{array}$ & $\begin{array}{c}\text { Fruit } \\
\text { drop } \\
(\%)\end{array}$ \\
\hline 7 & $2.70 \mathrm{~d}$ & $23.27 \mathrm{e}$ & $82.85 \mathrm{~d}$ & $17.15 \mathrm{a}$ \\
\hline 9 & $3.20 \mathrm{c}$ & $26.96 \mathrm{~d}$ & $85.23 \mathrm{c}$ & $14.77 \mathrm{~b}$ \\
\hline 11 & $3.33 \mathrm{c}$ & $28.98 \mathrm{c}$ & $86.31 \mathrm{c}$ & $13.69 \mathrm{~b}$ \\
\hline 13 & $3.70 \mathrm{~b}$ & $31.52 \mathrm{~b}$ & $88.26 \mathrm{~b}$ & $11.74 \mathrm{c}$ \\
\hline 15 & $4.10 \mathrm{a}$ & $33.40 \mathrm{a}$ & $91.25 \mathrm{a}$ & $8.75 \mathrm{~d}$ \\
\hline 7 & $2.76 \mathrm{e}$ & $21.81 \mathrm{e}$ & $82.12 \mathrm{e}$ & $17.88 \mathrm{a}$ \\
\hline 9 & $2.97 \mathrm{~d}$ & $25.94 \mathrm{~d}$ & $84.18 \mathrm{~d}$ & $15.82 \mathrm{~b}$ \\
\hline 11 & $3.17 \mathrm{c}$ & $27.36 \mathrm{c}$ & $85.48 \mathrm{c}$ & $14.52 \mathrm{c}$ \\
\hline 13 & $3.44 \mathrm{~b}$ & $30.13 \mathrm{~b}$ & $88.31 \mathrm{~b}$ & $11.69 \mathrm{~d}$ \\
\hline 15 & 3.63 a & $32.10 \mathrm{a}$ & 90.91 a & $9.09 \mathrm{e}$ \\
\hline
\end{tabular}

Means designated with the same letter in the same column are not significantly different at 0.05 level of probability.

set was discussed by Lavee and Wodner (1992) on olive, as they mentioned that, dry soil conditions decreased the number of flowers. Moreover, RuizSanchez et al., (1999) on apricot and Hussein (2004) on pear mentioned that, increasing the amount of applied water increased flower number per shoot and fruit setting.

Concerning fruit retention, there was a significant difference between all treatments. Irrigation at $15 \mathrm{~m}^{3} /$ tree/year recorded the highest fruit retention percentage ( 91.25 and $90.91 \%$ in the 2007 and 2008 seasons, respectively) while the lowest fruit retention percentage $(82.85$ and $82.12 \%$ ) was attained by irrigation at $7 \mathrm{~m}^{3} /$ tree/ year.

Considering fruit drop percentage, the highest significant fruit drop percentage took place with irrigation at $7 \mathrm{~m}^{3} /$ tree/ year while the lowest fruit drop was observed by irrigation level at 15 $\mathrm{m}^{3} /$ tree/ year.

Increasing fruit retention and reducing fruit drop with high irrigation rate are in harmony with results of Lavee and Wodner (1992) on olive, who reported that the fruit retention increased and fruit drop decreased as the irrigation rate increased. Also, Chauhan et al. (2005) on apple and Ruiz-Sanchez et al., (1999) on apricot found that, drought stress increased fruitlet drop.

3.4. Fruit physical properties at harvest time

Effect of irrigation levels on fruit dimensions and fruit size are illustrated in Table (4). Fruit length and diameter $(\mathrm{cm})$ gradually increased in both seasons with increasing irrigation level. The biggest fruit length and diameter were produced from trees irrigated with $15 \mathrm{~m}^{3} /$ tree/year, while the smallest fruit length and

Table (4): Effect of irrigation levels on fruit length $(\mathrm{cm})$, fruit diameter $(\mathrm{cm})$ and fruit size $(\mathrm{cm} 3)$ of pomegranate $\mathrm{c} v$. Manfalouty fruits in the $2007-2008$ seasons.

\begin{tabular}{|c|c|c|c|}
\hline $\begin{array}{c}\begin{array}{c}\text { Irrigation } \\
\text { levels } \\
\left(\mathbf{m}^{3} / \text { tree/ }\right.\end{array} \\
\text { year) }\end{array}$ & $\begin{array}{c}\text { Fruit } \\
\text { Length } \\
\text { (cm) }\end{array}$ & $\begin{array}{c}\text { Fruit } \\
\text { diameter } \\
(\mathrm{cm})\end{array}$ & $\begin{array}{c}\text { Fruit } \\
\text { volume } \\
\left(\mathrm{cm}^{3}\right)\end{array}$ \\
\hline \multicolumn{4}{|c|}{2007 Season } \\
\hline 7 & $7.91 \mathrm{~d}$ & $7.14 \mathrm{~d}$ & $264.0 \mathrm{e}$ \\
\hline 9 & $8.26 \mathrm{c}$ & $7.57 \mathrm{c}$ & $285.3 \mathrm{~d}$ \\
\hline 11 & $8.94 \mathrm{~b}$ & 8.27 b & 337.0 c \\
\hline 13 & $9.47 \mathrm{a}$ & $8.53 \mathrm{ab}$ & 354.7 b \\
\hline 15 & $9.63 \mathrm{a}$ & 8.83 a & 375.7 a \\
\hline \multicolumn{4}{|c|}{2008 Season } \\
\hline 7 & $7.64 \mathrm{e}$ & $6.85 \mathrm{e}$ & 248.7 e \\
\hline 9 & $8.07 \mathrm{~d}$ & $7.09 \mathrm{~d}$ & $274.7 \mathrm{~d}$ \\
\hline 11 & $8.56 \mathrm{c}$ & $7.62 \mathrm{c}$ & $318.4 \mathrm{c}$ \\
\hline 13 & $9.17 \mathrm{~b}$ & 8.12 b & $336.0 \mathrm{~b}$ \\
\hline 15 & $9.47 \mathrm{a}$ & $8.56 \mathrm{a}$ & 355.0 a \\
\hline
\end{tabular}

Means designated with the same letter in the same column are not significantly different at 0.05 level of probability

diameter resulted from irrigation at $7 \mathrm{~m}^{3} /$ tree/ year. These results are in line with those of ElKhoreiby and Salem (1989) on guava, and Abd El-Moteleb (1998) on apple, as they concluded that the highest fruit size was recorded from moist treatment, and the lowest fruit dimensions were obtained due to drought treatment.

According to fruit size, it is evident that fruit size increased significantly as irrigation rate increased, reaching the greatest values (375.7 and $355.0 \mathrm{~cm}^{3}$ in the 2007 and 2008 seasons, respectively) with irrigation at $15 \mathrm{~m}^{3} /$ tree/ year. These results are in harmony with those reported by Chauhan et al. (2005) on apple, Kandil and ElFeky (2006) on apricot as they illustrated that trees produced the biggest fruits when subject to 
the highest irrigation rate, and the smallest fruit resulted from lowest irrigation.

Data in Table (5) show the effect of irrigation levels on fruit grain, fruit juice and fruit peel percentage. Concerning fruit grain (\%) it increased significantly with increasing irrigation level. Irrigation at $15 \mathrm{~m}^{3} /$ tree/ year gave the highest values of fruit grain (65.13 and $65.46 \%$ ), while the lowest values (49.60 and $57.45 \%$ ) were recorded by irrigation at $7 \mathrm{~m}^{3} /$ tree/ year in both seasons of study. These results agree with EIKassas (1983) and (1984) on pomegranate c v. Manfalouty who found that the grain weight (\%) increased by increasing soil moisture level.

Table (5): Effect of irrigation levels on fruit grain $(\%)$, fruit juice $(\%)$ and fruit peel $(\%)$ of Manfalouty pomegranate fruits in 2007 and 2008 seasons

\begin{tabular}{|c|c|c|c|}
\hline $\begin{array}{l}\text { Irrigation } \\
\text { levels } \\
\left(\mathbf{m}^{3} / \text { tree }\right. \\
\text { /year })\end{array}$ & $\begin{array}{c}\text { Fruit } \\
\text { grain } \\
(\%)\end{array}$ & $\begin{array}{c}\text { Fruit } \\
\text { juice } \\
(\%)\end{array}$ & $\begin{array}{c}\text { Fruit peel } \\
(\%)\end{array}$ \\
\hline 7 & $49.60 \mathrm{e}$ & $33.50 \mathrm{e}$ & $50.40 \mathrm{a}$ \\
\hline 9 & $55.13 \mathrm{~d}$ & $36.30 \mathrm{~d}$ & $44.87 \mathrm{~b}$ \\
\hline 11 & $58.77 \mathrm{c}$ & $40.60 \mathrm{c}$ & $41.23 \mathrm{c}$ \\
\hline 13 & $62.53 \mathrm{~b}$ & $44.29 \mathrm{a}$ & $37.47 \mathrm{~d}$ \\
\hline 15 & $65.13 \mathrm{a}$ & $42.99 \mathrm{~b}$ & $34.87 \mathrm{e}$ \\
\hline 7 & $57.45 \mathrm{e}$ & $35.00 \mathrm{e}$ & $42.55 \mathrm{a}$ \\
\hline 9 & $59.43 \mathrm{~d}$ & $36.00 \mathrm{~d}$ & $40.57 \mathrm{~b}$ \\
\hline 11 & $61.07 \mathrm{c}$ & $39.63 \mathrm{c}$ & $38.93 \mathrm{c}$ \\
\hline 13 & $63.15 \mathrm{~b}$ & $46.50 \mathrm{a}$ & $36.85 \mathrm{~d}$ \\
\hline 15 & $65.46 \mathrm{a}$ & $45.26 \mathrm{~b}$ & $34.54 \mathrm{e}$ \\
\hline
\end{tabular}

Means designated with the same letter in the same column are not significantly different at 0.05 level of probability.

In both seasons, irrigation at $13 \mathrm{~m}^{3} /$ tree/ year gave the highest significant fruit juice percentage (44.29 and $46.50 \%$ ) followed by irrigation rates of 15,11 and $9 \mathrm{~m}^{3} /$ tree/ year while $7 \mathrm{~m}^{3} /$ tree/ year gave the lowest value of fruit juice (33.50 and $35.00 \%)$. In this sphere, EI-Kassas (1983) and (1984), Lawand and Patil (1996) on pomegranate and El-Gendy (2002) on grape mentioned that the percentage of juice increased by increasing soil moisture level.

In addition, fruit peel percentage decreased significantly with increasing irrigation levels. Whereas the highest fruit peel percentage $(50.40$ and $42.55 \%$ in 2007 and 2008 respectively) was recorded by irrigation at $7 \mathrm{~m}^{3} /$ tree/ year and the

Table (6): Effect of irrigation levels on fruit weight (gm), yield (kg/tree), fruit cracking (\%) and water use efficency $\left(\mathrm{kg} / \mathrm{m}^{3}\right.$ water) of pomegranate c.v. Manfalouty in 2007 and 2008 seasons

\begin{tabular}{|c|c|c|c|c|}
\hline $\begin{array}{c}\text { Irrigation } \\
\text { levels } \\
\text { (m/tree/ } \\
\text { year) }\end{array}$ & $\begin{array}{c}\text { Fruit } \\
\text { weight } \\
\text { (gm) }\end{array}$ & $\begin{array}{c}\text { Yield } \\
\text { (kg/tree) }\end{array}$ & $\begin{array}{c}\text { Fruit } \\
\text { cracking } \\
(\%)\end{array}$ & $\begin{array}{l}\text { WUE } \\
\left(\mathrm{kg} / \mathrm{m}^{3}\right. \\
\text { water })\end{array}$ \\
\hline \multicolumn{5}{|c|}{2007 Season } \\
\hline 7 & 230.86 e & 20.47 e & 8.58 a & $2.92 \mathrm{c}$ \\
\hline 9 & $251.08 \mathrm{~d}$ & $25.61 \mathrm{~d}$ & $7.27 \mathrm{c}$ & 2.85 c \\
\hline 11 & 298.94 c & 33.87 c & $6.85 \mathrm{~d}$ & 3.08 b \\
\hline 13 & $321.03 \mathrm{~b}$ & $41.83 \mathrm{~b}$ & $6.02 \mathrm{e}$ & $3.22 \mathrm{a}$ \\
\hline 15 & 331.19 a & 44.81 a & $7.93 \mathrm{~b}$ & $2.98 \mathrm{bc}$ \\
\hline \multicolumn{5}{|c|}{2008 Season } \\
\hline 7 & 214.94 e & $17.41 \mathrm{e}$ & 8.99 a & $2.49 \mathrm{~d}$ \\
\hline 9 & $245.81 \mathrm{~d}$ & $22.86 \mathrm{~d}$ & 8.22 c & $2.54 \mathrm{~cd}$ \\
\hline 11 & 287.12 c & $29.20 \mathrm{c}$ & $6.72 \mathrm{~d}$ & $2.65 \mathrm{bc}$ \\
\hline 13 & 306.89 b & 37.84 b & $6.09 \mathrm{e}$ & $2.91 \mathrm{a}$ \\
\hline 15 & 316.42 a & 40.09 a & $8.65 \mathrm{~b}$ & $2.67 \quad b$ \\
\hline
\end{tabular}

Means designated with the same letter in the same column are not significantly different at 0.05 level of probability.

lowest (34.87 and $34.54 \%$ ) was recorded with irrigation at $15 \mathrm{~m}^{3} /$ tree/ year in 2007 and 2008 season respectively. This result is in agreement with El-Khawaga et al. (2007) who found that increasing duration of water withholding from one to three weeks before maturation caused a gradual increase in fruit peel (\%).

As regards fruit weight, yield, fruit cracking and WUE, the data in Table (6) indicate that, fruit weight significantly increased with increasing irrigation levels. Trees produced the heaviest fruits (331.19 and $316.42 \mathrm{gm}$ in the 2007 and 2008 seasons, respectively) when subjected to the highest irrigation level $\left(15 \mathrm{~m}^{3} /\right.$ tree/ year) followed in descending order by those trees under irrigation at $13,11,9$ then $7 \mathrm{~m}^{3} /$ tree/ year which produced the lowest fruit weight.

Considering yield, there was a significant increase in the tree yield as irrigation level increased reaching the greatest (44.81 and 40.09 $\mathrm{Kg}$ ) with irrigation at $15 \mathrm{~m}^{3} /$ tree/ year compared with the other treatments. On the other hand lowest yield $(20.47$ and $17.41 \mathrm{Kg}$ ) was detected with the lowest irrigation level $\left(7 \mathrm{~m}^{3} /\right.$ tree/ year). 
These results agree with those mentioned by Hussein (2004) and Abd El-Samad et al. (2006) on pear; Kandil and El-Feky (2006) on apricot, as they concluded that the highest fruit weight and yield $(\mathrm{kg} /$ tree) were obtained on trees which received the highest irrigation rate.

Regarding fruit cracking (\%), it was reduced significantly with increasing irrigation level from 7 to 9,11 and $13 \mathrm{~m}^{3} /$ tree/ year, then it increased with irrigation at $15 \mathrm{~m}^{3} /$ tree/ year. The lowest significant fruit cracking (6.02 and 6.09\% in 2007 and 2008, respectively) was recorded by irrigation at $13 \mathrm{~m}^{3} /$ tree/ year. These results are in line with those reported by EI-Kassas (1983) and (1984), Prasad et al (2003) and El-Khawaga et al. (2007) on pomegranate, who stated that, by increasing soil moisture level, fruit cracking (\%) was decreased.

Concerning WUE, the highest significant WUE (3.22 and $2.91 \mathrm{~kg} / \mathrm{m}^{3}$ water) was found in trees grown under irrigation at $13 \mathrm{~m}^{3} /$ tree/year. The values decreased with either decreasing or increasing water quantity than $13 \mathrm{~m}^{3} /$ tree/ year. Irrigation at $7 \mathrm{~m}^{3} /$ tree/ year gave the lowest WUE $\left(2.92\right.$ and $2.49 \mathrm{~kg} / \mathrm{m}^{3}$ water in 2007 and 2008 seasons respectively). Similar results showing that trees receiving more frequent irrigation had greater water use than trees receiving less frequent irrigation under similar climatic conditions were recorded by Smitle et al., (1994), Abd- El-Samad, (2001) on orange, and Abd-El-Samad (2005)on guava.

\subsection{Fruit chemical properties at harvest time}

Data in Table (7) show the effect of irrigation levels on fruit TSS, acidity and TSS/ acid ratio. Generally, TSS decreased by increasing irrigation level but no significant differences were found between all treatments except between irrigation at $7 \mathrm{~m}^{3} /$ tree/ year and $15 \mathrm{~m}^{3} /$ tree/ year in the second season only. The same result was stated by EI-Kassas (1983), Lawand and Patil (1996) and Afria et al. (1998) on pomegranate, as they found that TSS decreased by increasing soil moisture level.

In addition, total acidity decreased significantly with increasing irrigation level. The highest significant fruit acidity (2.03 and $2.16 \%$ in 2007 and 2008, respectively) was obtained by irrigation at $7 \mathrm{~m}^{3} /$ tree/ year. Meanwhile, the lowest fruit acidity (1.51 and $1.58 \%$ ) was recorded by irrigation at $15 \mathrm{~m}^{3} /$ tree/ year. These results are in agreement with Lawand and Patil (1996) on pomegranate, Abd El-Samad et al. (2006) on pear and Kandil and El-Feky (2006) on
Table (7): Effect of irrigation levels on TSS (\%), total acidity (\%) and TSS/ acid ratio of Manfalouty pomegranate fruits in 2007 and 2008 seasons

\begin{tabular}{|c|c|c|c|}
\hline $\begin{array}{c}\text { Irrigation } \\
\text { levels } \\
\left(\mathrm{m}^{3} / \text { tree/ }\right. \\
\text { year })\end{array}$ & $\begin{array}{c}\text { TSS } \\
(\%)\end{array}$ & $\begin{array}{c}\text { Total } \\
\text { acidity } \\
(\%)\end{array}$ & $\begin{array}{c}\text { TSS /acid } \\
\text { ratio }\end{array}$ \\
\hline 7 & $16.50 \mathrm{a}$ & $2.03 \mathrm{a}$ & $8.13 \mathrm{~d}$ \\
\hline 9 & $16.33 \mathrm{a}$ & $1.78 \mathrm{~b}$ & $9.17 \mathrm{c}$ \\
\hline 11 & $16.33 \mathrm{a}$ & $1.73 \mathrm{~b}$ & $9.44 \mathrm{c}$ \\
\hline 13 & $16.17 \mathrm{a}$ & $1.39 \mathrm{~d}$ & $11.63 \mathrm{a}$ \\
\hline 15 & $16.17 \mathrm{a}$ & $1.51 \mathrm{c}$ & $10.71 \mathrm{~b}$ \\
\hline 7 & $16.17 \mathrm{a}$ & $2.16 \mathrm{a}$ & $7.49 \mathrm{~d}$ \\
\hline 9 & $16.17 \mathrm{a}$ & $1.96 \mathrm{~b}$ & $8.25 \mathrm{c}$ \\
\hline 11 & $16.00 \mathrm{ab}$ & $1.64 \mathrm{c}$ & $9.76 \mathrm{~b}$ \\
\hline 13 & $15.83 \mathrm{ab}$ & $1.43 \mathrm{e}$ & $11.07 \mathrm{a}$ \\
\hline 15 & $15.67 \mathrm{~b}$ & $1.58 \mathrm{~d}$ & $9.92 \mathrm{~b}$ \\
\hline
\end{tabular}

Means designated with the same letter in the same column are not significantly different at 0.05 level of probability

apricot, as they stated that, the highest fruit acidity was observed with the lowest irrigation rate.

TSS/ acid ratio increased significantly with increasing irrigation level till $13 \mathrm{~m}^{3} /$ tree/ year. The highest TSS/acid ratio (11.63 and 11.07in 2007 and 2008, respectively) resulted from irrigation at $13 \mathrm{~m}^{3} /$ tree/ year, while the lowest values $(8.13$ and 7.49) were recorded with $7 \mathrm{~m}^{3} /$ tree/ year. Similar results were obtained by Smirnov et al.(1986) on grapevines and Verreynne et al. (2001) on clementine, as they reported that TSS/acid ratio was increased with increasing the level of irrigation.

Results in Table (8) show the effect of irrigation levels on total sugar, vitamin $\mathrm{C}$ and anthocyanin contents of pomegranate fruits. By increasing irrigation level the total sugar content decreased. Whereas irrigation at $7 \mathrm{~m}^{3} /$ tree/ year gave the highest total sugar (14.8 and $14.98 \%)$, irrigation at $15 \mathrm{~m}^{3} /$ tree/ year had the lowest total sugar (13.44 and 13.4\%). These results are in line with those of Ibrahim (2005) on mango and ElKhawaga et al. (2007) on pomegranate, who concluded that, the highest total sugar content resulted from the lowest irrigation levels. 
Table (8): Effect of irrigation levels on total sugar (\%), vitamin C (mg. scorbic acid/ $100 \mathrm{ml}$ juice) and total anthocyanin (\%) of Manfalouty pomegranate fruits in 2007 and 2008 seasons

\begin{tabular}{|c|c|c|c|}
\hline $\begin{array}{c}\text { Irrigation } \\
\text { levels } \\
\left(\mathbf{m}^{3} / \text { tree/ }\right. \\
\text { year) }\end{array}$ & $\begin{array}{c}\text { Total } \\
\text { sugars } \\
(\%)\end{array}$ & $\begin{array}{l}\text { Vitamin } \\
\text { (c) (mg. } \\
\text { scorbic } \\
\text { acid/ } 100 \\
\text { ml juice) }\end{array}$ & $\begin{array}{c}\text { Total } \\
\text { anthocyanin } \\
\text { content }(\%)\end{array}$ \\
\hline \multicolumn{4}{|c|}{2007 Season } \\
\hline 7 & 14.80 a & $17.13 \mathrm{a}$ & $5.82 \mathrm{a}$ \\
\hline 9 & $14.35 \mathrm{~b}$ & $16.52 \mathrm{~b}$ & 5.16 b \\
\hline 11 & $14.00 \mathrm{bc}$ & $15.93 \mathrm{c}$ & $4.95 \mathrm{~b}$ \\
\hline 13 & $13.73 \mathrm{~cd}$ & $15.31 \mathrm{~d}$ & $4.48 \mathrm{c}$ \\
\hline 15 & $13.44 \mathrm{~d}$ & $14.80 \mathrm{e}$ & $4.01 \mathrm{~d}$ \\
\hline \multicolumn{4}{|c|}{2008 Season } \\
\hline 7 & $14.98 \mathrm{a}$ & $16.37 \mathrm{a}$ & $7.66 \mathrm{a}$ \\
\hline 9 & $14.57 \mathrm{~b}$ & $15.80 \mathrm{~b}$ & $6.91 \mathrm{~b}$ \\
\hline 11 & $14.24 \mathrm{c}$ & $15.12 \mathrm{c}$ & $6.77 \mathrm{~b}$ \\
\hline 13 & $13.65 \mathrm{~d}$ & $14.77 \mathrm{~d}$ & $6.29 \mathrm{c}$ \\
\hline 15 & $13.40 \mathrm{~d}$ & $14.22 \mathrm{e}$ & $6.05 \mathrm{~d}$ \\
\hline
\end{tabular}

Means designated with the same letter in the same column are not significantly different at 0.05 level of probability

Concerning vitamin C (V.C), irrigation at 7 $\mathrm{m}^{3} /$ tree/ year gave the highest (V.C) content, while the lowest content, resulted from irrigation at 15 $\mathrm{m}^{3} /$ tree/ year. High vitamin C content may serve as a protective strategy against drought injury (Seung and Kader, 2000). This result was confirmed by EI-Kassas (1983) on pomegranate c v. Manfalouty, who stated that ascorbic acid decreased by increasing soil moisture. An opposite trend was noticed by El-Khoreiby and Salem (1989) on guava, who indicated that increasing soil moisture content increased V.C content.

In addition, the total anthocyanin content decreased by increasing irrigation levels. Irrigation at $7 \mathrm{~m}^{3} /$ tree/ year gave the highest significant total anthocyanin content (5.82 and $7.66 \%$ in 2007 and 2008, respectively ) while irrigation at $15 / \mathrm{m}^{3} /$ tree/season gave the lowest total anthocyanin content (4.01 and $6.05 \%$ in both seasons). Water stress enhances secondary metabolism in particular anthocyanin biosynthesis as part of the stress response (Kevin et al., 2009). These results are in parallel to those reported by,
Kilili et al., (1996), Abd El-Moteleb (1998) on apple trees, and El-Gendy (2002) on grape, who showed that anthocyanin concentration was higher with drought treatment.

\section{REFERENCES}

A. O. A. C. (1985). Official Methods of Analysis. $14^{\text {th }}$ Ed. Washington,(D.C.)USA

Abd El-Moteleb M. M. M. (1998). Response of Apple Trees to Some Irrigation Treatments in New Reclaimed Soils. Ph.D. Thesis, Fac. of Agric., Hort. Dept, Ain Shams Univ., Egypt.

Abd El-Samad G.A. (2001). Water use and productivity of Navel and Acidless orange trees as affected by deficit irrigation. Fayoum J. Agric. Res. \& Dev., 15( 1): 150- 159.

Abd El-Samad G.A. (2005). Water use, growth and productivity of some new guava strain as affected by different irrigation regimes. Egypt. J. Hort. Vol 32 p. 41- 56.

Abd El-Samad G.A., Morsi M.E. and Yehia T.A. (2006). Effect of organic fertilizers and irrigation levels on water use, growth and productivity of pear trees. Egypt. J. of Appl. Sci., 21 (12B). 695- 712.

Abou El-Wafa M. (2002). Effect of Some Treatments on Drought Resistance of Transplants of Some Pomegranate Cultivars. M.Sc. Thesis, Fac. of Agric., Cairo Univ., Egypt.

Afria B.S., Garg D.K. and Singh K. (1998). Effect of trickle irrigation on pomegranate in semiarid region. Annals of Agricultural Research. 19: (4), 494-495.

Ahmed R.B. (1994). Response of pomegranate (Punica granatum L.) transplants to different soil moisture stress and growth retardant Cycocel treatments. Annal of Agric. Sci. Moshtohor, 32 (3) 1651- 1663.

Beaumont P. (1993). Dryland Environmental Management and Development. Routledge, London and New York pp. 536 (210-215).

Behnia A. (1999). Comparison of different irrigation methods for pomegranate orchards in Iran. Irrigation under conditions of water scarcity. Vol 1C. $17^{\text {th }}$ ICID International Congress on Irrigation and Drainage, Granada, Spain, 13 - 17 September 207-217.

Blumenfeld A. (1995). Underutilized fruit crops in the Mediterranean region Zaragoza, CIHEAM-IAMZ. 31-38.

Brown J.D. and Lilleland D. (1946). Rapid determination of potassium and sodium in plant material and soil extract by flame photometer. Proc. Amer. Soc. Hort. Sci. Vol. (48), p. 341. 
Centeral Administration for Agricultural Economics (2007). Agriculture statistics, Ministry of Agriculture and Land Reclamation , V.(2):275.

Chapman H.D. and Pratt P.F. (1961). Methods of Analysis for Soils, Plants and Waters. Div. of. Agric. Sci., Univ. Calif, U.S.A. 309 pp.

Chauhan P.S., Sud A., Sharma L.K. and Mankotia M.S. (2005). Studies on the effect of microirrigation levels on growth, yield, fruit quality and nutrient assimilation of Delicious apple. Proc. VII ${ }^{\text {th }}$ on TZFTS. Acta Hort., 696; 193196.

Chopade S.O., Gorantiwar S.D., Pampattiwar P.S. and Supe V.S. (2001). Response of pomegranate to drip, bubbler and surface irrigation methods. Advances in Hort. and Forestry. Scientific Publishers India Jodhpur, 8: 53-59.

Devid A.G., Elias F., Merce M. and Moshe G. (1999). Sensitivity of continuous and discrete plant and soil water status monitoring in peach trees subjected to deficit irrigation. J. Amer. Soc. Hort. Sci., 124: 437- 444.

Dubois M., Gilles K., Hamiton J.K., Rebers P.A. and Smith F. (1956). A calorimetric method for the determination of sugars and related substances. Anal. Chem. 28: 350.

Duncan D.B. (1955). Multiple range and multiple F test. Biometrics, 11: 1-24.

El-Gendy R.S. (2002). Utilization of Evapotranspiration Data for Use in Irrigation for Thompson and Flame Seedless Grapevines. Ph.D. Thesis, Fac. of Agric., Cairo Univ., Egypt.

EI-Kassas S.E. (1983). Effect of irrigation at certain soil moisture levels and nitrogen application on the yield and quality of Manfalouty pomegranate cultivar. Assiut J. of Agric. Sci, 14 (2): 167- 179.

EI-Kassas S.E (1984). Seasonal changes in growth and maturation of Manfalouty pomegranate fruits under certain soil moisture levels. Assiut J. of Agric. Sci, 15 (1) : 81-91.

El- Khawaga A.S., Abou-El-Khashab A.M. and El-Eraky M.A. (2007). Impact of water withholding before ripening, zinc and glutathione on fruit splitting and productivity of Manfalouty pomegranate trees. Minia J. of Agric. Res. Develop. 27(3):481-496.

El-Khoreiby A.M.K. and Salem A.T.O. (1989). Effect of different irrigation regimes on growth, fruiting and fruit quality of seedy guava trees. Annals Agric. Sci., Fac. Agric., Ain Shams Univ., 34 (1): 313- 321.
Hsia C.L., Luh B.S. and Chickester C.O. (1965). Anthocyanin in fresstone peaches. J. Food, Sci, 30: 5-12.

Hussein S.M.M. (2004). Effect of Different Irrigation Levels on the Le-Cont Pear Trees. Ph.D. Thesis, Fac. of Agric., Cairo Univ., Egypt.

Ibrahim A. R. (2005). Studies on the Determination of Water Requirements of Mango Trees Under Giza Governorate Condition Using Agrometeorological Data. M.Sc. Thesis, Fac. of Agric., Hort. Dept., Ain Shams Univ., Egypt.

Kandil E.A. and El-Feky U.S. (2006). Effect of soil matric potential on Canino apricot trees in sandy soil under drip irrigation. J. Agric. Sci. Mansoura Univ., 31 (9) 5867- 5880.

Kevin G., Kevin D. and Chris W. (2009). Anthocyanins Biosynthesis, Functions and Applications. Springer Science+ Business Media pp. 345 (120-122).

Kilili A.W., Behboudlan M.H. and Mills T.M. (1996). Postharvest performance of Braeburn apples in relation to withholding of irrigation at different stages of growing season. J. of Hort. Sci. 71 (5): 693- 701. (C.F. Hort. Abst. 67, 1019).

Lavee S. and Wodner M. (1992). Factors affecting the nature of oil accumulation in fruit of olive. J. of Hort. Sci. 66 (5): 583- 591.

Lawand B.T. and Patil V.K. (1996). Effect of different water regimes on fruit quality of pomegranate (Punica granatum L.). International Journal of Tropical Agriculture. 14: (1/4): 153-158.

Meti C.B., Aladakatti Y.R., Khot A.B., Patil P.L., Mudkavi D.H., Radder B.M. and Patil S.G. (2008). Studies on optimum wetted area and pan fraction for higher yield and water use efficiency of pomegranate in vertisols of Malaprabha command area. Karnataka J. of Agricultural Sci. 21(3): 469-470.

Murphy J. and Riely J.P. (1962). A modified single dilution method for determination of phosphate in natural water. Ann. Chem. Acta, 27: 31-36.

Naguib M.L. (1969). Colourimetric determination of nitrogen components of plant tissues. Bull. Fac. Agric. Cairo Univ., 43:1.

Prasad R.N., Bankar G.J. and Vashishtha B.B. (2003). Effect of drip irrigation on growth, yield and quality of pomegranate in arid region. Indian J. of Hort., 60 (2) 140-142.

Ruiz-Sanchez M.C., Egea J., Galego R. and Torrecillas A. (1999). Floral biology of Bulida apricot trees subjected to postharvest 
drought stress. Annals of Applied Biology 135 (2): 523- 528. (Hort. Abst. 70, 3703).

Salisbury F.B. and Ross C.W. (1985). Plant Physiology. Wadsworth Pub. Co.,Calif., USA. $185 \mathrm{pp}$.

Seung K.L. and A. A. Kader (2000). Preharvest and postharvest factors influencing vitamin $\mathrm{C}$ content of horticultural crops. Postharvest Biology and Technology (20): 207-220

Smirnov K.V., Shishkin P.V. and Salenkov S.N. (1986). Effect of mineral nutrition and water supply on the productivity of seedless grapevine culture Kishmish Cherngi treated with gibberellin. Vinodlie. I. Vinogradarstvo. SSSR. No 3, 10-13.
Smitle D.A., Dickens W. and Stansell J.R. (1994). Irrigation regimes affect yield and water use by Bell pepper. J. Amer. Soc. Hort. Sci. 119, 936.

Snedecor G.W. and Cochran W.G. (1980). Statistical Methods. Oxford and J. B. H. Bub Com. $7^{\text {th }}$ Edition.

Verreynne J.S., Rabe E. and Theron K.I. (2001). The effect of combined deficit irrigation and summer trunk girdling on the internal fruit quality of Marisol clementines. Scientia Horticulturae, 91: 25- 37.

Wright J.L. and Stark J.C. (1990). Irrigation of agricultural crops. Amer. Soc. Agron., 30: 112- 117.

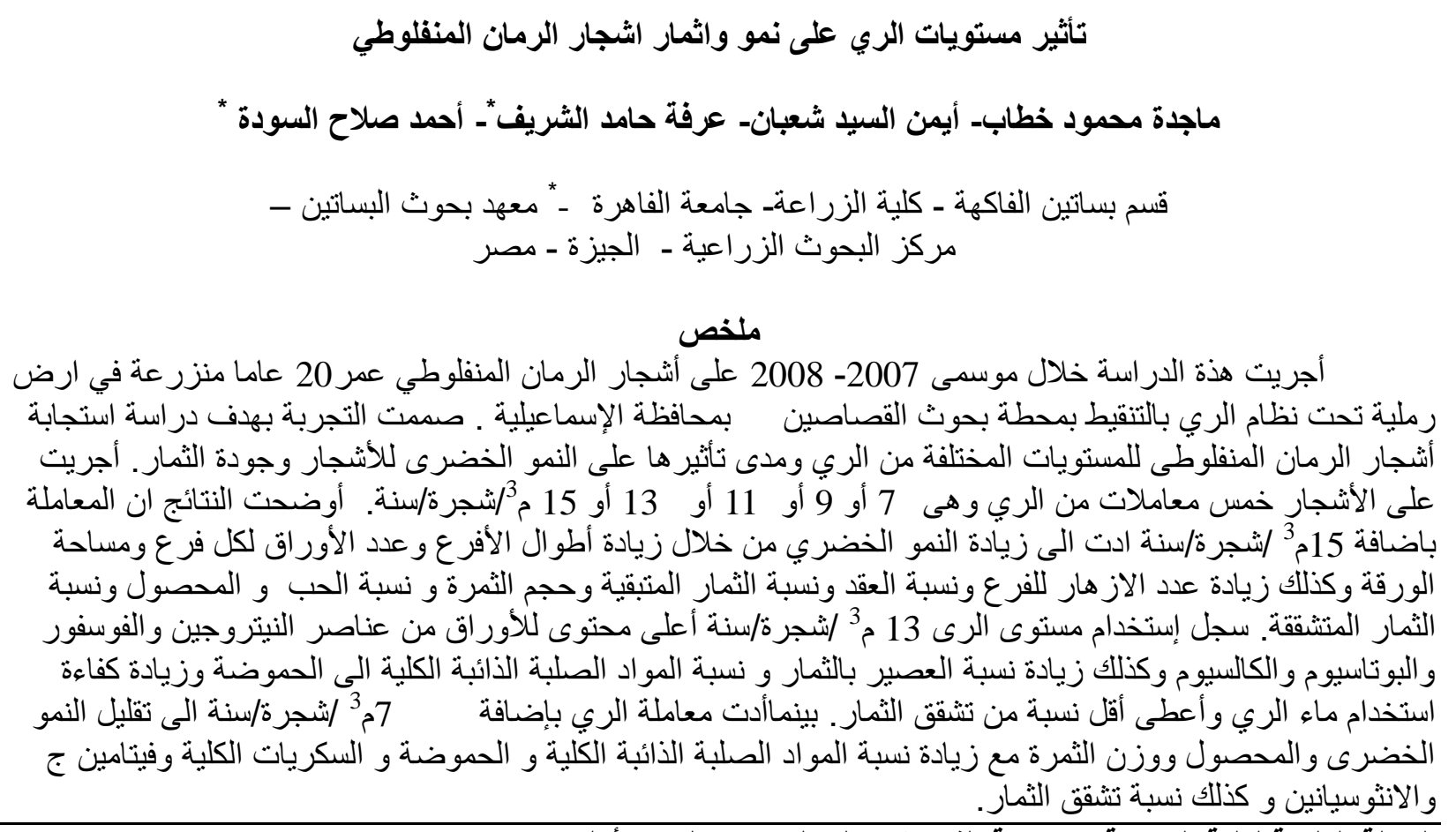

المجلة العلمية لكلية الزراعة ـ جامعة القاهرة ـ المجلد (61) العدد الأول (يناير 2010): 16-8. 